\title{
Records of Dicephalic (Two-headed) Snakes from India
}

\author{
Amit Sayyed \\ Wildlife Protection and Research Society, Satara, Maharashtra (amitsayyedsatara@gmail.com)
}

$\mathrm{I}_{w}^{\mathrm{h}}$ herein report four dicephalic snakes from India. Three were Russell's Vipers (Daboia russelii) and the fourth was a Trinket Snake (Coelognathus helenus), a species for which dicephaly is reported here for the first time.

One two-headed Russell's Viper (Fig. 1) was captured on 23 July 2006 by local villagers in the Kheri District, Uttar Pradesh. This snake moved very slowly and it did not respond even after being perturbed. It died in the captivity of villagers on 27 July 2006 (Mishra 2006). A second two-headed juvenile Russell's Viper (Fig. 2) was caught on 14 August 2008 by a snake catcher on a rescue call at Saswad Taluka Purandar (18 $\left.20^{\prime} 27^{\prime \prime} N, 74^{\circ} 2^{\prime} 18^{\prime \prime} E\right)$, Pune, Maharashtra. This snake died within a day. The specimen was deposited in the collection of the Zoological Survey of India (ZSI) at Pune (R/1038). Another two-headed juvenile Russell's Viper (Fig. 3) was found on 6 July 2013 during a rescue call at Bastora near Mapusa (1535'0”N, 7349'7”E), Bastora Goa. The snake was turned over to the local forestry department, where it died after two days in captivity.

A juvenile Trinket Snake (Figs. 4 \& 5) was caught on 19 February 2014 during a rescue call by local snake friends at Kiroli Chakan (18'43'6”N, 7350'56”E), Pune, Maharashtra.

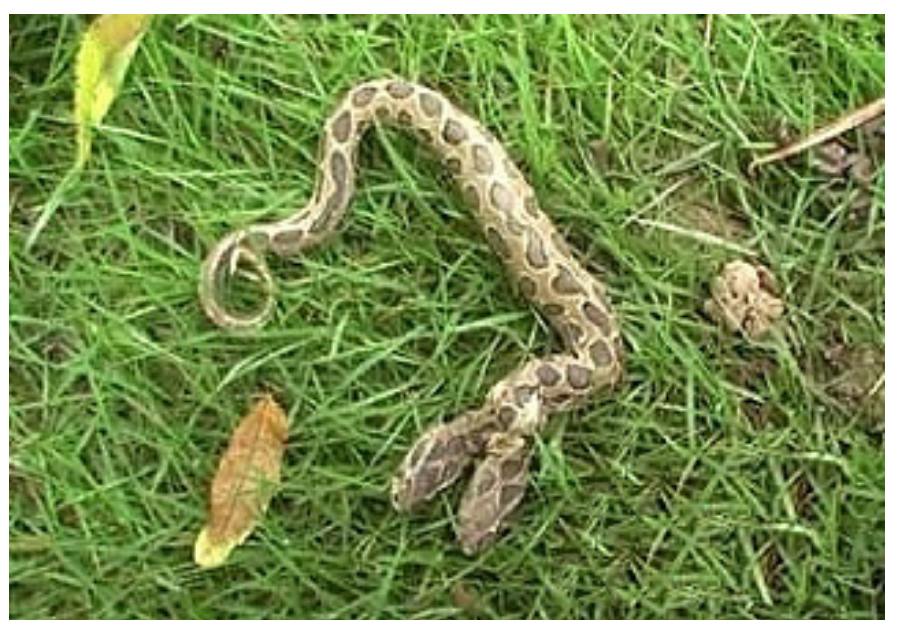

Fig. 1. A dicephalic Russell's Viper (Daboia russelii) captured in 2006. Total length was $252 \mathrm{~mm}$. Photograph by Krishna Mishra.
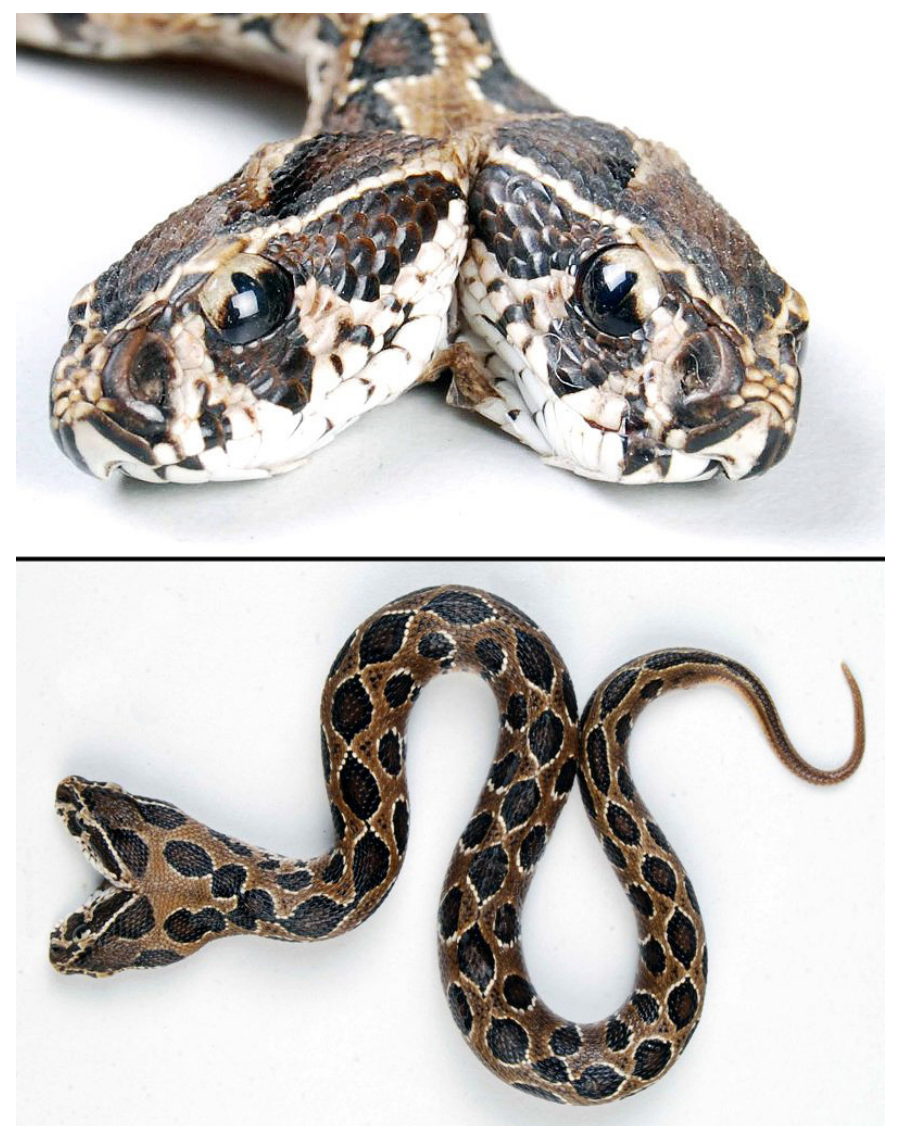

Fig. 2. A dicephalic Russell's Viper (Daboia russelii) captured in 2008. Total length was $228.6 \mathrm{~mm}$; distance from the rostrals to the bifurcation was $13 \mathrm{~mm}$. Photographs by Krushna Ghule.

After examination, it was taken to the Pimpri-Chinchwad Zoo in Pune. An x-ray (Fig. 5) showed that the heads separate at a fork in the spine; the anatomy of this snake otherwise appears to be normal. Keeping this snake at the zoo provided an opportunity to examine its behavior. The snake is unable to move easily and appears to have a great deal of difficulty deciding in which direction to go.

Cunningham (1937) used the term "polycephaly" for this type of disorder in animals, which results from abnormal 


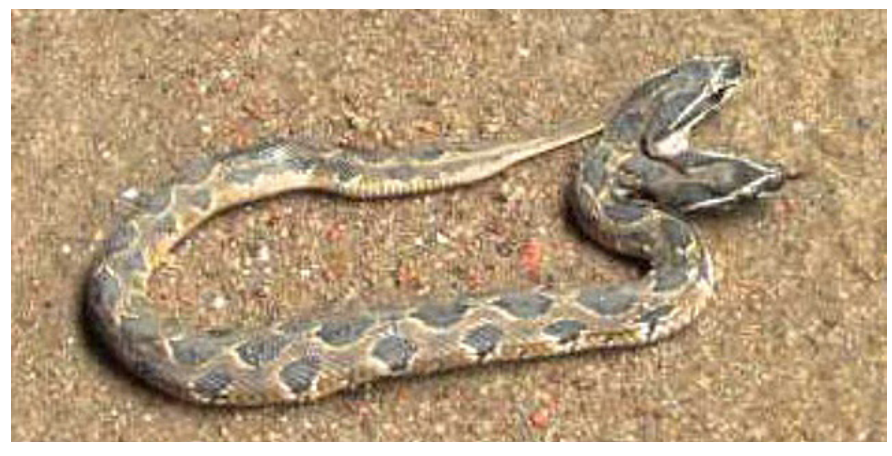

Fig. 3. A dicephalic Russell's Viper (Daboia russelii) captured in 2013. Total length was $234 \mathrm{~mm}$. Photograph by Amrut Singh.

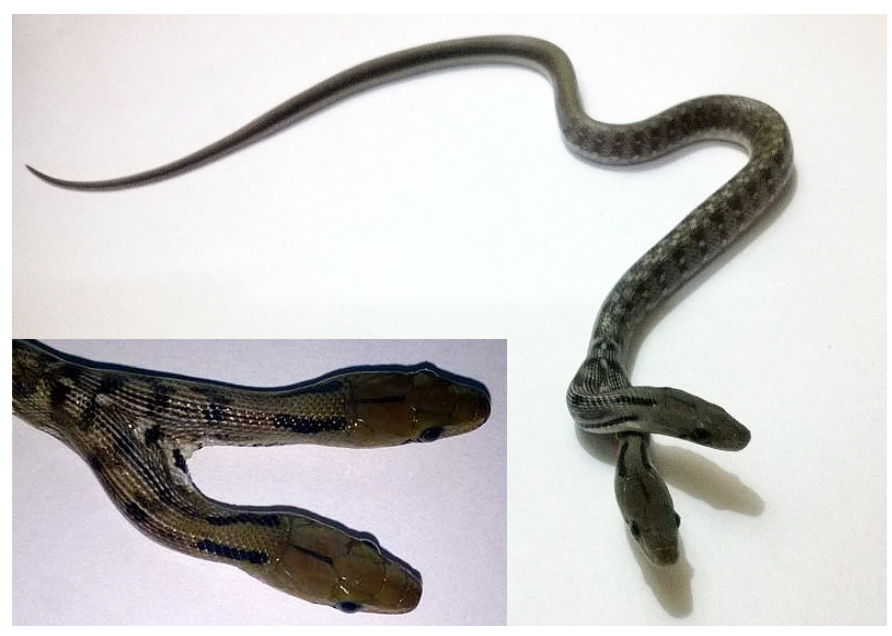

Fig. 4. A dicephalic Trinket Snake (Coelognathus helenus) captured in 2014. Total length was $426.7 \mathrm{~mm}$; distance from the rostrals to the bifurcation was $30 \mathrm{~mm}$. Photographs by Bapusaheb Sonawane.

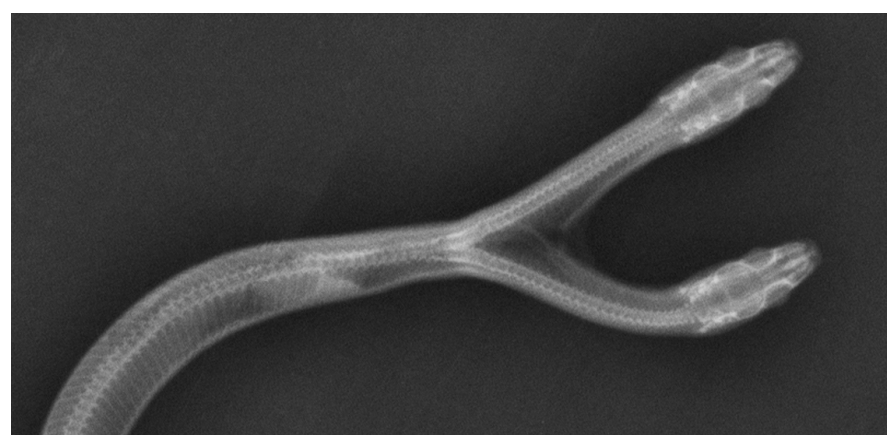

Fig. 5. X-ray of a dicephalic Trinket Snake (Coelognathus helenus) captured in 2014. Photograph by Amit Kamat. development. The word is derived from the Greek "poly-" (= many) and kephalé (= head) and encompasses both bicephaly and dicephaly, either referring to two-headedness. Dicephaly is seen occasionally in reptiles, with the most commonly observed two-headed animals being turtles and snakes (Anina 2003). About 400 instances of dicephalic snakes have been recorded (Matz 2001).

Each head of a dicephalic animal has its own brain, and they somehow share control of the organs and limbs, although the specific structure of the connection varies. Animals often move in a disoriented fashion, with the two brains unable to coordinate control. Dicephalic individuals rarely survive in nature, largely attributable to problems with directional movement and prey capture (Derickson 1927). However, two-headed turtles and snakes have survived for more than a few years in captivity. The record is held by a snake at the World Aquarium, an interactive animal exhibition and rehabilitation center located in the City Museum in St. Louis, Missouri, United States. "We," a dicephalic albino Western Ratsnake (Pantherophis obsoletus), died naturally after eight years (Leonard 2007).

\section{Acknowledgments}

I thank Dr. Hemant Ghate, Dr. Anil Mahabal, Anilkumar Khaire, and Tejas Khaire for their support; Dr. Amit Kamat for performing the x-ray of Coelognathus helenus; Krushna Ghule, Subhas Ghule, and Bapusaheb Sonawane for allowing me to observe two-headed snakes; and Krishna Mishra and Amrut Singh for providing me with information and photographs of Daboia russelii.

\section{Literature Cited}

Anina, S. 2003. Two-headed creatures. 29 November 2003. Pravda.ru. <http:// english.pravda.ru/science/tech/29-11-2003/4201-anomaly-0>.

Cunningham, B. 1937. Axial Bifurcation in Serpents. Duke University Press, Durham, North Carolina.

Derickson, S.H. 1927. A twin turtle. The Science Monthly 25:562-565.

Leonard, C. 2007. 'We' the 2-headed snake's long odd life ends. 20 June 2007. Associated Press. <http://www.nbcnews.com/id/19334041/ns/technology_and_science-science/t/we--headed-snakes-long-odd-life-ends/\#.VQBLyihQVQ>.

Matz, G. 2001. Tératologie, pp. 106-107. In: R. Bauchot (ed.), Serpents. Artémis, Paris, France.

Mishra, K.K. 2006. Two-headed snake found. This is a Siamese twins [sic] not evolution. 23 July 2006. Dudhwa Jungles. <http://dudhwa.blogspot.com>. 